Research article

Open Access

\title{
Induction of arthritis by high mobility group box chromosomal protein 1 is independent of tumour necrosis factor signalling
}

\author{
Rille Pullerits ${ }^{1}$, Ing-Marie Jonsson ${ }^{1}$, George Kollias ${ }^{2}$ and Andrej Tarkowski ${ }^{1}$
}

\author{
1Department of Rheumatology and Inflammation Research, Sahlgrenska Academy at Göteborg University, Guldhedsgatan 10A, 41346, Göteborg, \\ Sweden \\ 2Institute of Immunology, Biomedical Sciences Research Center 'Alexander Fleming', 34 Al. Fleming Street, 16672 Vari, Greece \\ Corresponding author: Rille Pullerits, rille.pullerits@rheuma.gu.se
}

Received: 18 Mar 2008 Revisions requested: 24 Apr 2008 Revisions received: 29 May 2008 Accepted: 26 Jun 2008 Published: 26 Jun 2008

Arthritis Research \& Therapy 2008, 10:R72 (doi:10.1186/ar2445)

This article is online at: http://arthritis-research.com/content/10/3/R72

(C) 2008 Pullerits et al.; licensee BioMed Central Ltd.

This is an open access article distributed under the terms of the Creative Commons Attribution License (http://creativecommons.org/licenses/by/2.0), which permits unrestricted use, distribution, and reproduction in any medium, provided the original work is properly cited.

\begin{abstract}
Introduction TNF $\alpha$ and high mobility group box chromosomal protein 1 (HMGB1) are two potent proinflammatory cytokines implicated as important mediators of arthritis. Increased levels of these cytokines are found in the joints of rheumatoid arthritis patients, and the cytokines trigger arthritis when applied into the joints of naïve mice. HMGB1 is actively released from immune cells in response to TNF $\alpha$; once released, HMGB1 in turn induces production of several proinflammatory cytokines including IL-6 and TNF $\alpha$ - by macrophages. Whether HMGB1induced arthritis is mediated via the TNF $\alpha$ pathway, however, is unknown. The purpose of the present study was to investigate whether the arthritis-inducing effect of HMGB1 is dependent on TNF $\alpha$ expression in vivo and to assess whether TNF $\alpha$ deficiency affects a proinflammatory cytokine response to HMGB1 in vitro.
\end{abstract}

Methods TNF $\alpha$ knockout mice and backcrossed control animals on a C57BI6 background were injected intraarticularly with $5 \mu \mathrm{g} \mathrm{HMGB1}$. Joints were dissected 3 days after intraarticular injection and were evaluated histologically by scoring the frequency and severity of arthritis. For in vitro studies, mouse spleen cultures from TNF $\alpha$ knockout mice and from control mice were incubated with different doses of
HMGB1, and cell culture supernatants were collected at different time points for analysis of IL-6.

Results Intraarticular injection of HMGB1 into healthy mouse joints resulted in an overall frequency of $32 \%$ to $39 \%$ arthritic animals. No significant differences were found with respect to the severity and incidence of synovitis between mice deficient for TNF $\alpha$ (seven out of 18 mice with arthritis) in comparison with control $\mathrm{TNF}^{+/+}$animals (six out of 19). No significant differences were detected between spleen cells from TNF $\alpha^{+/+}$ mice versus $\mathrm{TNF} \alpha^{-/}$mice regarding IL- 6 production upon stimulation with highly purified HMGB1 after 24 hours and 48 hours. Upon stimulation with a suboptimal dose of recombinant HMGB1, however, the splenocytes from TNF $\alpha^{+/+}$animals released significantly more IL-6 than cells from the knockout mice $(602 \pm 112 \mathrm{pg} / \mathrm{ml}$ and $304 \pm 50 \mathrm{pg} / \mathrm{ml}$, respectively; $P<$ 0.05).

Conclusion Our data show that HMGB1-triggered joint inflammation is not mediated via the TNF pathway. Combined with our previous study, we suggest that HMGB1-triggered arthritis is probably mediated through IL-1 activation.

\section{Introduction}

Rheumatoid arthritis is an autoimmune disease characterized by chronic inflammation in the joints leading to destruction of articular cartilage and bone. The pathogenesis of the disease is complex, involving a wide range of cytokines and endogenous proinflammatory molecules.
High mobility group box chromosomal protein 1 (HMGB1), a nuclear DNA-binding protein, proved recently to be a potent proinflammatory cytokine implicated as an important mediator of arthritis [1]. Increased levels of HMGB1 are found in the joints of rheumatoid arthritis patients $[2,3]$, and the protein triggers arthritis when applied into the joints of naïve mice [4]. HMGB1 is actively released from immune cells in response to

$\mathrm{H} \& \mathrm{E}=$ haematoxylin and eosin; HMGB1 = high mobility group box chromosomal protein 1; IFN = interferon; IL = interleukin; LPS = lipopolysaccharide; $\mathrm{pHMGB1}=$ purified recombinant endotoxin-free high mobility group box chromosomal protein 1 ; rHMGB1 = mouse recombinant high mobility group box chromosomal protein $1 ; \mathrm{TNF}=$ tumour necrosis factor. 
different stimuli, including TNF $\alpha$ and lipopolysaccharide (LPS). Previous studies have reported that IFN- $\gamma$ plays an important role in the regulation of HMGB1 release partly through a TNF $\alpha$-dependent mechanism [5]. Chen and colleagues demonstrated that direct suppression of TNF activity with neutralizing antibodies or genetic disruption of TNF expression partially attenuated LPS-induced HMGB1 release from macrophages [6]. Once released, HMGB1 generates a positive feedback loop and in turn induces production of several proinflammatory cytokines - such as IL-6, IL-1 $\beta$ and TNF $\alpha$ - by macrophages, thereby sustaining prolonged inflammation [7].

To what extent the ability of HMGB1 to induce arthritis is mediated via the TNF $\alpha$ pathway and whether the presence of TNF $\alpha$ gene affects the proinflammatory cytokine production in response to HMGB1, however, are unknown. In the present study we examined whether the HMGB1-induced joint inflammation is dependent on TNF $\alpha$ signalling.

\section{Materials and methods Mice}

Female and male TNF $\alpha$ knockout mice and backcrossed control animals on a C57BI6 background were bred at the Institute of Immunology, Biomedical Sciences Research Center 'Al. Fleming', Greece. The animals were housed in the animal facility of the Department of Rheumatology and Inflammation Research, University of Göteborg, Sweden. The mice were kept under standard conditions of temperature and light, and were fed laboratory chow and water ad libitum. The study was approved by the Ethical Committee of Göteborg University, and the requisitions of the National Board for Laboratory Animals were followed.

\section{Reagents}

Mouse recombinant HMGB1 (rHMGB1) was expressed in Escherichia coli and purified to homogeneity as previously described [8]. Preparations were tested for LPS content by the chromogenic Limulus amebocyte lysate assay and contained $<2 \mathrm{ng}$ endotoxin/ $\mu \mathrm{g}$ rHMGB1. Highly purified recombinant endotoxin-free HMGB1 (pHMGB1) (purchased from HMGBiotech, Milano, Italy) was also used for experiments. LPS from E. coli serotype 055:B5 was purchased from Sigma (Saint Louis, MO, USA).

\section{Injection protocol}

In the first experiment, TNF $\alpha^{-/-}$mice and backcrossed control animals on a C57BI6 background were injected intraarticularly with $5 \mu \mathrm{g}$ pHMGB1. In the second experiment, mice received the intraarticular injection of $5 \mu \mathrm{g}$ rHMGB1 and the contralateral knee was injected with 10 ng LPS, which corresponded to the amount of LPS found in rHMGB1 preparations.

\section{Histologic examination}

Three days after the intraarticular injections, the optimal time to trigger synovitis [4], the mice were sacrificed. The knee joints were removed, fixed in 4\% formaldehyde, decalcified, embedded in paraffin, sectioned and stained with H\&E. All of the slides were assessed in a blinded manner by two researchers (RP and AT). The extent of synovitis was judged on an arbitrary scale from grade 0 to grade 3 , as described elsewhere [4].

\section{In vitro experiments}

Spleen cells from TNF $\alpha^{-/}$mice and from control mice were prepared as previously described [9] and were stimulated with different doses of rHMGB1 and pHMGB1. The corresponding amount of LPS from $E$. coli was used for cell stimulation as a control for rHMGB1. Cell culture supernatants were collected after 24 hours and 48 hours for determination of the IL- 6 level, as previously described [9].

For the in vitro proliferation assay, splenocyte cultures were prepared; the cells were then incubated for 72 hours in 96well plates with final concentrations of $0.05 \mu \mathrm{g} / \mathrm{ml}, 0.5 \mu \mathrm{g} / \mathrm{ml}$, and $5 \mu \mathrm{g} / \mathrm{ml}$ pHMGB1. Culture medium was used as a negative control, and concavalin A at a concentration of $2.5 \mu \mathrm{g} / \mathrm{ml}$ as a positive control. The cultures were pulsed with $1 \mu \mathrm{Ci}$ tritiated thymidine 12 hours before harvesting, and the tritiated thymidine uptake was counted in a beta counter. The proliferative response is expressed as the mean \pm standard error of the mean (median) counts per minute of triplicate samples from five spleens in each group.

\section{Statistical analysis}

Nonparametric methods were used for statistical comparisons since the data showed a non-normal distribution. Statistical differences between independent groups were calculated using the Mann-Whitney $U$ test. $P<0.05$ was considered significant.

\section{Results}

\section{Induction of arthritis by HMGB1 in TNF $\alpha^{-/-}$mice and in} control mice

To assess the importance of the TNF $\alpha$ signalling pathway in HMGB1-triggered arthritis, TNF $\alpha^{-/-}$mice and control TNF $\alpha^{+/+}$ mice were given a single intraarticular injection of $5 \mu \mathrm{g}$ pHMGB1 into a knee joint. This dose has been established in previous experiments to induce arthritis [4]. Intraarticular injection of HMGB1 into healthy mouse joints resulted in an overall frequency of $32 \%$ to $39 \%$ arthritic animals as assessed histologically. No significant differences were found with respect to the severity and incidence of arthritis between mice deficient for TNF $\alpha$ (seven out of 18 mice with arthritis) in comparison with control TNF $\alpha^{+/+}$animals (six out of 19). The inflammation was characterized by mild synovitis (Figure 1). 
Figure 1

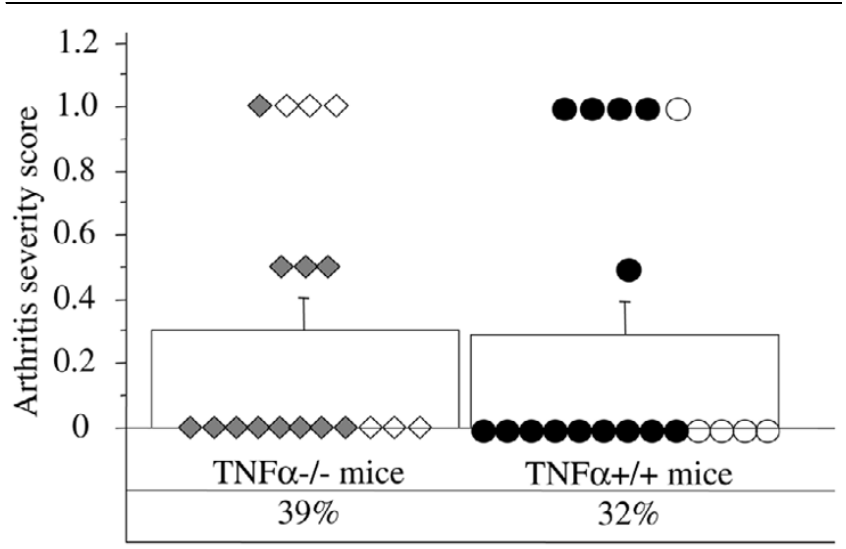

Arthritis induction by high mobility group box chromosomal protein 1 in $\mathrm{TNF} \alpha^{-1-}$ mice and controls. Arthritis incidence (\%) and arthritis severity scores (mean \pm standard error of the mean) are shown in TNF $\alpha^{-/}$mice (squares) and in control mice (circles) ( $n=18$ to 19 per group) following a single intraarticular injection of $5 \mu \mathrm{g}$ high mobility group box chromosomal protein 1 (HMGB1). Empty squares/circles, individual mice ( $n$ = five to six per group) receiving recombinant HMGB1 containing a minimal amount of lipopolysaccharide (see Materials and methods); filled squares/circles, mice ( $n=12$ to 14 per group) receiving lipopolysaccharide-free HMGB1.

Six mice in both groups received $5 \mu \mathrm{g}$ rHMGB1 intraarticularly, which is known to contain a higher concentration of LPS. As a control, the contralateral knee joint of those mice was injected with $10 \mathrm{ng}$ LPS, a dose corresponding to the LPS present in the rHMGB1 preparations used for injection. We could not observe any significant differences regarding arthri- tis severity in mice receiving $\mathrm{rHMGB} 1$ between mice with or mice without the functional TNF $\alpha$ gene (Figure 1). Two mice out of the six injected with $10 \mathrm{ng}$ LPS displayed mild synovitis in both groups irrespective of the presence or absence of the TNF $\alpha$ gene. These results indicate that HMGB1 induces joint inflammation in vivo independently of the TNF $\alpha$ pathway.

\section{Cytokine response to HMGB1 in TNF-/- mice}

We next examined whether TNF $\alpha$ deficiency affects a proinflammatory cytokine response to HMGB1 in vitro. Mouse splenocytes from $\mathrm{TNF}^{-/-}$mice and from control $\mathrm{TNF} \alpha^{+/+}$mice were stimulated with $0.05 \mu \mathrm{g}, 0.5 \mu \mathrm{g}$ and $5 \mu \mathrm{g} \mathrm{pHMGB} 1$ for 24 hours and 48 hours, and the IL- 6 production in cell culture supernatants was determined. Stimulation with pHMGB1 did not induce significant IL- 6 release from TNF $\alpha^{-/}$cells as compared with $\mathrm{TNF}^{+/+}$splenocytes at any time point and irrespective of the pHMGB1 concentration used (Table 1).

In another experiment, spleen cells from $\mathrm{TNF}^{-/-}$mice and from control mice were prepared and stimulated with $0.5 \mu \mathrm{g} / \mathrm{ml}$ and $5 \mu \mathrm{g} / \mathrm{ml} \mathrm{rHMGB} 1$ for 24 hours and 48 hours. As a control, the splenocytes were stimulated with $10 \mathrm{ng}$ LPS, a dose corresponding to that present in the highest HMGB1 preparations. The results show that, upon stimulation with $0.5 \mu \mathrm{g} / \mathrm{ml}$ rHMGB1, the TNF $\alpha^{+/+}$cells released significantly more IL-6 than cells from the knockout mice after 24 hours $(P<0.05)$ and 48 hours $(P<0.03)$ (Table 1). No significant differences were detected, however, between spleen cells from TNF $\alpha^{+/+}$ mice versus $\mathrm{TNF}^{-1-}$ mice regarding IL-6 production upon stim-

\section{Table 1}

Production of IL-6 following 24 hours and 48 hours of stimulation with different doses of purified recombinant endotoxin-free high mobility group box chromosomal protein 1 (pHMGB1) and mouse recombinant high mobility group box chromosomal protein 1 (rHMGB1)

\begin{tabular}{|c|c|c|c|c|c|c|}
\hline \multirow[t]{2}{*}{ Time } & \multirow[t]{2}{*}{ Mice } & \multicolumn{4}{|c|}{ IL-6 production (pg/ml) } & \multirow[t]{2}{*}{ Lipopolysaccharide ${ }^{a}$} \\
\hline & & $0 \mu \mathrm{g} / \mathrm{ml} \mathrm{HMGB} 1$ & $0.05 \mu \mathrm{g} / \mathrm{ml} \mathrm{HMGB} 1$ & $0.5 \mu \mathrm{g} / \mathrm{ml} \mathrm{HMGB} 1$ & $5 \mu \mathrm{g} / \mathrm{ml}$ HMGB1 & \\
\hline \multicolumn{7}{|l|}{ PHMGB1 } \\
\hline \multirow[t]{2}{*}{24 hours } & TNF $\alpha^{-/-}$ & $17.0 \pm 2.3$ & $17.6 \pm 2.2$ & $17.8 \pm 2.4$ & $13.1 \pm 4.6$ & $2,460 \pm 226$ \\
\hline & $\mathrm{TNF} \alpha^{+/+}$ & $16.2 \pm 1.9$ & $15.9 \pm 2.0$ & $16.8 \pm 3.2$ & $7.3 \pm 3.1$ & $6,905 \pm 1,763$ \\
\hline \multirow[t]{2}{*}{48 hours } & $\mathrm{TNF} \alpha^{-/-}$ & $19.1 \pm 3.0$ & $20.1 \pm 2.9$ & $17.0 \pm 1.6$ & $26.3 \pm 3.8$ & \\
\hline & TNF $\alpha^{+/+}$ & $19.8 \pm 2.2$ & $18.3 \pm 2.2$ & $14.2 \pm 2.3$ & $20.2 \pm 3.2$ & \\
\hline \multicolumn{7}{|l|}{ RHMGB1 } \\
\hline \multirow[t]{2}{*}{24 hours } & $\mathrm{TNF} \alpha^{-/-}$ & $28 \pm 16$ & & $304 \pm 50^{*}(314)$ & $2,317 \pm 264(2,271)$ & $146 \pm 46^{\star}(130)$ \\
\hline & TNF $\alpha^{+/+}$ & $68 \pm 11$ & & $602 \pm 112(558)$ & $3,046 \pm 757(2,504)$ & $344 \pm 63$ (359) \\
\hline \multirow[t]{2}{*}{48 hours } & $\mathrm{TNF} \alpha^{-/-}$ & $213 \pm 58$ & & $468 \pm 56^{\star}(500)$ & $2,541 \pm 258(2,588)$ & $238 \pm 79(207)$ \\
\hline & $\mathrm{TNF} \alpha^{+/+}$ & $263 \pm 33$ & & $1,133 \pm 202(1,062)$ & $4,114 \pm 941(3,527)$ & $438 \pm 62(408)$ \\
\hline
\end{tabular}

Data presented as the mean \pm standard error of the mean of 10 mice per each group (pHMGB1), and the mean \pm standard error of the mean (median) of four mice in each group (rHMGB1). HMGB1, high mobility group box chromosomal protein 1. apHMGB1, $5 \mu \mathrm{g} / \mathrm{ml}$; rHMGB1, $10 \mathrm{ng} /$ $\mathrm{ml} .{ }^{\star} P<0.05 \mathrm{TNF}^{-1 /}$ mice versus control mice. 
ulation with $5 \mu \mathrm{g} / \mathrm{ml} \mathrm{rHMGB} 1$ after 24 hours and 48 hours. As a control, stimulation with $10 \mathrm{ng} / \mathrm{ml}$ LPS (corresponding to the amount found in $5 \mu \mathrm{g} / \mathrm{ml}$ rHMGB1) induced approximately 100 times less IL- 6 than stimulation with $5 \mu \mathrm{g} / \mathrm{ml} \mathrm{rHMGB} 1$ in TNF $\alpha^{+/+}$cultures as well as TNF $\alpha^{-/-}$splenocyte cultures after 24 hours and 48 hours (Table 1 ).

\section{Proliferation}

To assess the impact of HMGB1 on the reactivity of immunocompetent cells in the presence or absence of the TNF $\alpha$ gene, spleen cells from TNF $\alpha^{+/+}$mice and from knockout mice were stimulated with different concentrations of endotoxin-free pHMGB1 and the proliferative response was scored after 72 hours. Upon stimulation with the highest HMGB1 dose $(5 \mu \mathrm{g} /$ $\mathrm{ml}), \mathrm{TNF}^{+/+}$mice had a significantly better proliferative response than their knockout littermates (285 \pm 51 (median 264) counts per minute versus $197 \pm 15$ (median 185) counts per minute, respectively; $P<0.05$ ), whereas no differences were seen regarding proliferation at lower HMGB1 concentrations (Figure 2). In addition, knockout mice had a threefold to fourfold lower response to concavalin $A$, a compound known to act on T lymphocytes, as compared with the TNF $\alpha^{+/+}$mice $(3,700 \pm 246$ (median 3,668) counts per minute versus 7,423 $\pm 1,043$ (median 6,550) counts per minute, respectively; $P=$ $0.009)$.

\section{Discussion}

In the present study we demonstrate that HMGB1-triggered joint inflammation is not mediated via the TNF pathway since the arthritis incidence and severity remained similar in mice deficient for TNF $\alpha$ and in backcrossed C57BI6 control animals.

We have previously shown that the overall frequency and severity of HMGB1-induced arthritis varies between different mouse strains. In the case of C57BI/ 6 mice, only 40\% develop arthritis - and the severity of inflammation in the joints also proved to be significantly lower in comparison with other mouse strains tested [4]. In the present study we observed mild synovial inflammation in $32 \%$ to $39 \%$ of mice upon intraarticular injection of HMGB1, which is in accordance with our previous report [4].

In our in vitro study we observed no differences regarding IL6 production from splenocyte cultures between $\mathrm{TNF}^{-/-}$mice and $\mathrm{TNF}^{+/+}$mice in response to stimulation with either endotoxin-free or LPS-containing HMGB1. The latter LPS-containing HMGB1, however, induced a much higher IL-6 response

Figure 2

(a)

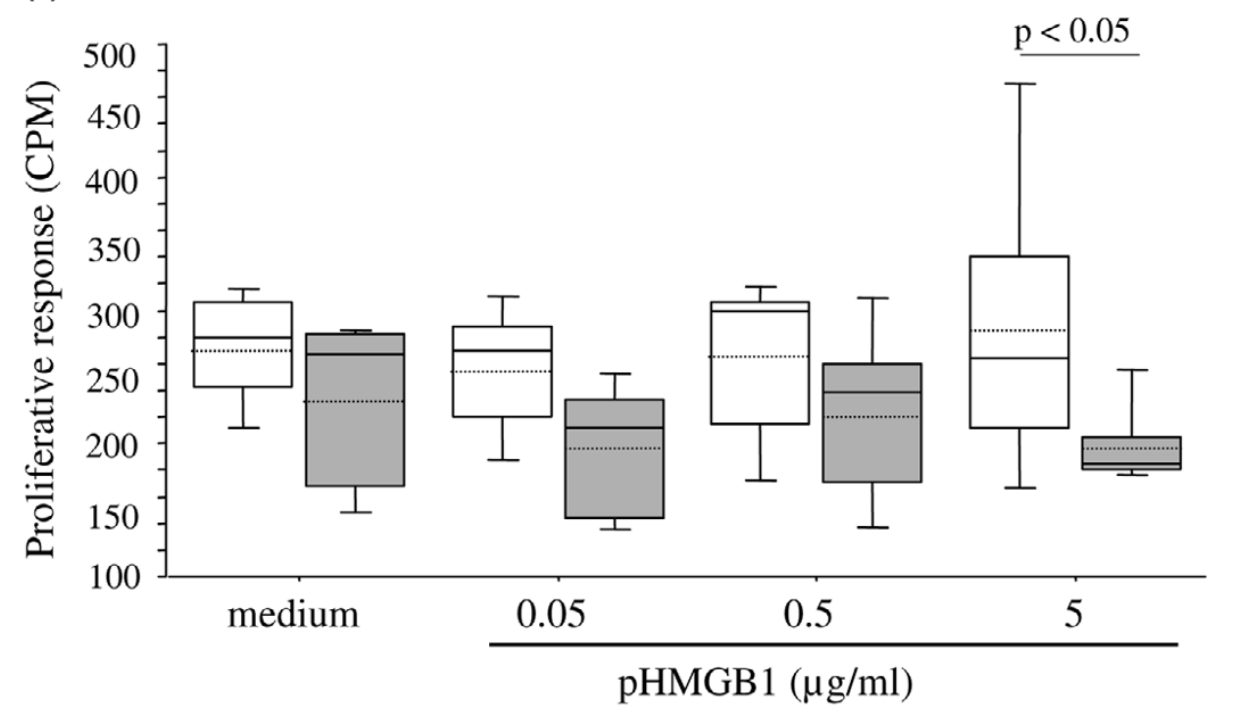

(b)

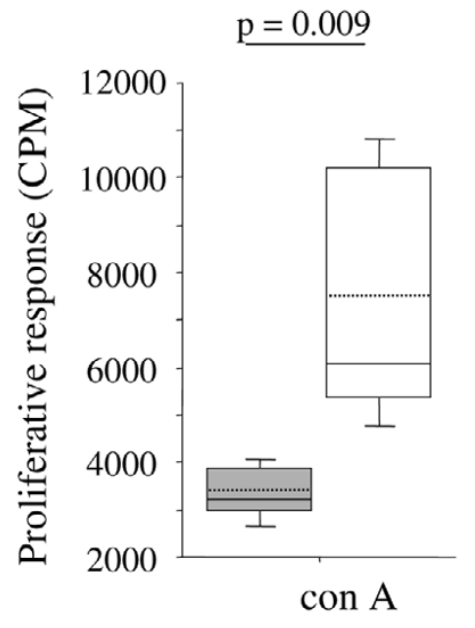

Impact of high mobility group box chromosomal protein 1 on reactivity in the presence/absence of TNF $\alpha$. Proliferative responses of splenocytes from TNF $\alpha^{+/+}$mice and from TNF $\alpha^{-/-}$mice ( $n=$ five mice per group) incubated with different doses of (a) lipopolysaccharide-free purified recombinant endotoxin-free high mobility group box chromosomal protein 1 (pHMGB1) or (b) concavalin A (con A). Box plots, 25th and 75th percentiles; horizontal solid lines, medians; horizontal hatched lines, means; vertical bars, 5th and 95th percentiles. Statistical differences were calculated using the Mann-Whitney U test. CPM, counts per minute. 
as compared with the endotoxin-free preparation. The higher activity of the recombinant HMGB1 to induce IL-6 release cannot be explained only by the endotoxin contamination since the corresponding dose of LPS found in HMGB1 preparations induced a 100-fold lower production of IL-6 than HMGB1. The synergistic effect of LPS and HMGB1 mediated via Toll-like receptor 4 could account for the increased production of proinflammatory IL-6 release demonstrated in our study.

HMGB1 is a potent inducer of several proinflammatory cytokines. One of these cytokines, IL-1, is considered a crucial mediator in the pathogenesis of destructive arthritis along with TNF $\alpha$ [7]. There is a great deal of crosstalk between IL- 1 and TNF $\alpha$ but their pathways differ nevertheless, and production of IL-1 may occur independently of TNF $\alpha$ [10]. In our previous study, we demonstrated that mice deficient for IL-1 receptor did not develop arthritis upon intraarticular administration of HMGB1 [4]. Furthermore, Park and colleagues reported in their study that TNF-receptor associated factor 2 - which is not associated with TLR/IL-1 receptor, but rather with TNF receptors - did not appear to be involved in HMGB1 signalling [11]. Sha and colleagues demonstrated recently that IL-1 $\beta$ was bound to HMGB1 isolated from cells cultured with this cytokine, and addition of anti-IL-1 $\beta$ antibodies or the IL-1 receptor antagonist to cell cultures blocked the proinflammatory activity of HMGB1 [12], further suggesting that the proinflammatory action of HMBG1 is likely to be mediated by IL-1 activation.

\section{Conclusion}

Our results show that pathways other than TNF $\alpha$ are involved in the initiation of joint inflammation in the case of HMGB1induced arthritis. Combined with our previous study [4], we suggest that HMBG1-triggered arthritis is probably mediated by IL-1 activation.

\section{Competing interests}

The authors declare that they have no competing interests.

\section{Authors' contributions}

RP participated in the design of the study, carried out all the experiments, performed the statistical analysis and drafted the manuscript. I-MJ performed the intraarticular injections and contributed to writing the manuscript. GK provided the TNF knockout/control mice and helped in manuscript preparation. AT conceived of the study, participated in its design and data interpretation, and helped to draft the manuscript. All authors read and approved the final manuscript.

\section{Acknowledgements}

The present work was supported by grants from the Göteborg Medical Society, the Swedish Medical Society, the Swedish Association against Rheumatism, the Göteborg Association against Rheumatism, the King Gustaf V foundation, the Swedish Medical Research Council, the Nanna Svartz Foundation, Stiftelsen Goljes Minne, and the University of Göteborg.

\section{References}

1. Andersson $\mathrm{U}$, Erlandsson-Harris $\mathrm{H}$ : $\mathrm{HMGB} 1$ is a potent trigger of arthritis. J Intern Med 2004, 255:344-350.

2. Taniguchi N, Kawahara K, Yone K, Hashiguchi T, Yamakuchi M, Goto M, Inoue K, Yamada S, ljiri K, Matsunaga S, Nakajima T, Komiya S, Maruyama I: High mobility group box chromosomal protein 1 plays a role in the pathogenesis of rheumatoid arthritis as a novel cytokine. Arthritis Rheum 2003, 48:971-981.

3. Kokkola R, Sundberg E, Ulfgren AK, Palmblad K, Li J, Wang H, Ulloa L, Yang H, Yan XJ, Furie R, Chiorazzi N, Tracey KJ, Andersson $\mathrm{U}$, Harris HE: High mobility group box chromosomal protein 1: a novel proinflammatory mediator in synovitis. Arthritis Rheum 2002, 46:2598-2603.

4. Pullerits $\mathrm{R}$, Jonsson IM, Verdrengh $\mathrm{M}$, Bokarewa $\mathrm{M}$, Andersson $\mathrm{U}$, Erlandsson-Harris $\mathrm{H}$, Tarkowski A: High mobility group box chromosomal protein 1, a DNA binding cytokine, induces arthritis. Arthritis Rheum 2003, 48:1693-1700.

5. Rendon-Mitchell $B$, Ochani M, Li J, Han J, Wang $H$, Yang $H$, Susarla S, Czura C, Mitchell RA, Chen G, Sama AE, Tracey KJ, Wang $\mathrm{H}$ : IFN-gamma induces high mobility group box 1 protein release partly through a TNF-dependent mechanism. $J$ Immunol 2003, 170:3890-3897.

6. Chen G, Li J, Ochani M, Rendon-Mitchell B, Qiang X, Susarla S, Ulloa L, Yang H, Fan S, Goyert SM, Wang P, Tracey KJ, Sama AE, Wang $\mathrm{H}$ : Bacterial endotoxin stimulates macrophages to release HMGB1 partly through CD14- and TNF-dependent mechanisms. J Leukoc Biol 2004, 76:994-1001.

7. Andersson $\mathrm{U}$, Wang $\mathrm{H}$, Palmblad $\mathrm{K}$, Aveberger AC, Bloom $\mathrm{O}$ Erlandsson-Harris $\mathrm{H}$, Janson $\mathrm{A}$, Kokkola $\mathrm{R}$, Zhang $\mathrm{M}$, Yang $\mathrm{H}$, Tracey KJ: High mobility group 1 protein $(\mathrm{HMG}-1)$ stimulates proinflammatory cytokine synthesis in human monocytes. J Exp Med 2000, 192:565-570.

8. Wang $\mathrm{H}$, Bloom $\mathrm{O}$, Zhang M, Vishnubhakat JM, Ombrellino M, Che J, Frazier A, Yang H, Ivanova S, Borovikova L, Manogue KR, Faist E, Abraham E, Andersson J, Andersson U, Molina PE, Abumrad NN, Sama A, Tracey KJ: HMG-1 as a late mediator of endotoxin lethality in mice. Science 1999, 285:248-251.

9. Pullerits R, Bokarewa M, Jonsson IM, Verdrengh M, Tarkowski A: Extracellular cytochrome c, a mitochondrial apoptosis-related protein, induces arthritis. Rheumatology (Oxford) 2005, 44:32-39.

10. Berg WB van den, Joosten LA, Loo FA van de: TNF alpha and IL1 beta are separate targets in chronic arthritis. Clin Exp Rheumatol 1999, 17:S105-S114.

11. Park JS, Svetkauskaite D, He Q, Kim JY, Strassheim D, Ishizaka A, Abraham E: Involvement of TLR 2 and TLR 4 in cellular activation by high mobility group box 1 protein (HMGB1). J Biol Chem 2004, 279:7370-7377.

12. Sha $Y, Z$ mijewski J, Xu Z, Abraham E: HMGB1 develops enhanced proinflammatory activity by binding to cytokines. J Immunol 2008, 180:2531-2537. 